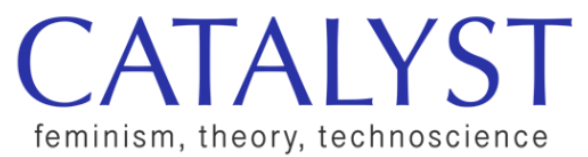

\title{
Coalition-Making and the Practice of Feminist STS in the Time of COVID-19
}

\author{
Hannah Fitsch \\ Technical University of Berlin \\ hannah.fitsch@tu-berlin.de \\ Anelis Kaiser Trujillo \\ University of Freiburg \\ anelis.kaiser@tf.uni-freiburg.de \\ Deboleena Roy \\ Emory University \\ droy2@emory.edu
}

\author{
Rebecca Jordan-Young \\ Barnard College \\ ryoung@barnard.edu \\ Cynthia Kraus \\ University of Lausanne \\ cynthia.kraus@unil.ch \\ Sigrid Schmitz \\ Humboldt University of Berlin \\ sigrid.schmitz@hu-berlin.de
}

\section{Abstract}

In this lab meeting, six feminist scholars who engage with the sciences from various perspectives and have been collaborating over the last decade as members of the NeuroGenderings Network, share a sustained discussion on the responsibilities of a feminist scientist-particularly in light of our current moment. In a time when ongoing acts of anti-Black racism and police brutality have converged with a global pandemic and anti-science movements, we ask ourselves, how do we express solidarity and also hold ourselves accountable at the crossroads of science and social justice? 


\section{Introduction}

\section{Deboleena Roy, Emory University}

It is indeed impossible for critical neuroscientists to evade the immense race(ism) and sexism pervading the theorizing and conceptualizing of mental difference, hence it is astounding that neuroscientists with a feminist persuasion continue to fail to demonstrate these interdependencies.

—Emily Ngubia Kuria, "Theorizing Race(ism) while NeuroGendering"

In early 2020, just before COVID-19 had registered as a serious global pandemic for some of Us, and just days before the brutal murder of Breonna Taylor in United States by the hands of police violence, the NeuroGenderings Network held its fifth periodic international conference. The theme of the conference was the "Intersectional Analysis of the Sexed/Gendered Brain." Organized by Katherine Bryant, Annelies Kleinherenbrink, Hannah Fitsch, Anelis Kaiser, and Mal Pool, the aim of this conference was to advance interdisciplinary conversations "surrounding sex/gender and the brain by integrating the notion of intersectionality more deeply into the field" of neuroscience, feminist STS, and where the two meet (NeuroGenderings, 2020).

Although the authors of this lab meeting all belong to the NeuroGenderings Network, this article is not intended to speak on behalf of the entire network. Having said that, the NeuroGenderings Network, which was formed in 2010, conceives itself as an "international and transdisciplinary network which aims to elaborate innovative theoretical and empirical approaches for questions of sex/gender and sexuality for neuroscientists" and, more broadly, for those interested in working with the neurosciences (NeuroGenderings, 2020). One of the goals of this network has included fostering collaborative and interdisciplinary research projects, with a concerted effort toward mentoring junior colleagues. Participants in this group have used primarily feminist and queer studies frameworks to critique how sex and gender differences are studied in the brain, and to develop new approaches to scientific inquiry and neuroscientific research that are informed by these critiques. Another goal of this network is to create a space for coalition building. We strive to raise a scientific voice as a community of scholars and not only as individuals in the neurosciences.

It is important to note that feminist scholars, including feminist neuroscientists who critique science, are not anti-science. We want to hold scientific research to a higher standard and produce knowledge that takes questions of ontology, epistemology, methodology, and ethics into mind. It is also important to note that feminist scholars who are critical of how the binary categories of sex and gender have been deployed in science are not against the idea of difference in 
biology. Rather, we are wary of the simplicity with which questions of difference are often formulated in the sciences.

As a feminist neuroscientist, I have benefited a great deal from working with this network of colleagues. Having said that, I think it is crucial at this moment to bring to the fore what Emily Ngubia Kessé (formerly Emily Ngubia Kuria), who was active in the earlier days of the network, highlighted above as a deep-seated failure on the part of this group. The NeuroGenderings Network, with all of its intentions of initiating dialogue across disciplinary boundaries, interrogating the categories of sex/gender, and thinking more productively about difference when it comes to the brain, continues to reproduce a "white norm" (Ngubia Kuria, 2014, p. 110, emphasis in original). This norm is evident both in the lack of Black, Indigenous, people of color (BIPOC) members who are actively involved in the network, in our citation politics, as well as the noticeable lack of scholarship being produced by its members that directly engages with critical race theory, Black and women of color feminisms, intersectionality, Indigenous, postcolonial and decolonial studies, and more.

As one of the very few persons of color who has had sustained interactions with this network (out of approximately one hundred members who have participated over the last decade), I know that many members are aware of the failure to address questions of race and racism in the NeuroGenderings Network-both in terms of representation and in terms of our scholarship. The admission of this failure, although on its own is certainly not enough, has been somewhat productive. The conference held in early 2020 is the closest that we have come as a network to directly confronting the limitations of our critical analyses of race and racism in neuroscience research. Our conference call invoked intersectionality as "an analytic framework for examining how various social identities, including race, class, gender, sexuality, and disability status are interwoven and impact each other" (NeuroGenderings, 2020). This is definitely a step in the right direction, but even so, as a group we have to make sure that we do not just tag on "race" as another category in our analyses and exacerbate what Kimberlé Crenshaw recently described as a mischaracterization of intersectionality-that is, as "identity politics on steroids" (quoted in Steinmetz, 2020). Rather, she states that intersectionality should be thought of as

a lens, a prism for seeing the way in which various forms of inequality often operate together and exacerbate each other. We tend to talk about race inequality as separate from inequality based on gender, class, sexuality or immigrant status. What's often missing is how some people are subject to all of these, and the experience is not just the sum of its parts. (Crenshaw quoted in Steinmetz, 2020) 
As feminist scientists and scholars who, for the most part, are not formally trained in critical race theory, we have a way to go to fully appreciate Crenshaw's understanding of intersectionality. In our efforts to analyze how various forms of inequality operate together and exacerbate each other in the context of neuroscience research, it is crucial that these efforts do not inadvertently conceptualize race in ways that end up reinforcing racist and eugenic traditions in neuroscience and biology. It is, for example, imperative that we learn how to think about the intersections of race and neuroscience more carefully and creatively, as in the work and the NeuroSpeculative AfroFeminism installation project envisioned by the artist and molecular and cellular biologist Ashley Baccus-Clark (2020a). We should also take questions of representation seriously and connect with scholars in the recently launched Black in Neuro organization who are dedicated to "celebrating Black excellence in neuroscience related fields" (Black in Neuro, 2020).

On the heels of our NeuroGenderings meeting dedicated to intersectionality, the six of us found ourselves posing some very difficult questions to each other. We all engage in our own way with the neurosciences, but we also all have many other feminist scholarly and political commitments. We asked, for instance, what does it mean to be a feminist in these times of the pandemic in which feminist priorities such as solidarity are set in opposition against individualism? What is our responsibility as feminist STS scholars in a time where the long histories of antiBlack racism have converged with right-wing, and predominantly "white-male," conservatism that promotes anti-science sentiments? What happens to feminist activism when we are forced to sacrifice our common spaces by social distancing? What have we done as feminist scientists in the past ten years that has contributed to anti-Black racism-either actively or through our inactions and our silences? What coalitions can we build to better bridge feminism, (neuro-)science, black feminist theory, critical race theory and activism outside of academia? Is the knowledge we produce relevant and readily accessible for those outside of academia? What can we do during this pandemic as feminist scientists who are not anti-science, but who are engaged in informed critiques of those scientific studies that oversimplify and misuse the categories of race, sex, gender, class, and more?

The entries that follow are borne out of our Zoom meeting discussions with each other since the pandemic began. They do not provide sufficient answers to our own questions. In fact, not all of the pieces engage directly with the neurosciences per se, but all come from a commitment to a feminist politics and investment in building feminist STS that brought us to the NeuroGenderings Network in the first place. At this moment, our lives are connected to each other through our joint worlds of feminism, science, activism, antiracism, and COVID. What is offered here is in the spirit of a lab meeting, where often germinal thoughts are planted, 
and where questions of protocol—what to do, and how on earth to proceed-also often find their way.

The first of these entries is by Dr. Hannah Fitsch, a STS postdoctoral fellow at the Technical University of Berlin, webmistress of the NeuroGenderings Network, and drummer for the band Point Pleasure. Hannah Fitsch studied sociology, biopsychology, and new media in Frankfurt/Main. She earned her PhD at the Technische Universität Berlin on visibilities and sayabilities in functional magnetic resonance imaging. She is currently working on a project called 'How Bodies Turn into Numbers and Numbers into Images | On Algorithms in Brain Research and the Logic of Standardization.' In her piece below, she comments on ways in which the virus, and health measures such as social distancing, challenge forms of political action and politically transformative ways of being that have previously fueled the vision and daily practices of leftist collectives. Based in Berlin, she shares her thoughts as an activist and feminist scholar on how to do political work in this moment. She argues that through this pandemic, we can see a politicization of private practices, while collective forms of political practices are being hindered. She sees this individualization of political subjects as a key problem for the pandemic, drawing from resonances that are also prevalent in neuroscientific models promoting separate and autonomous subjects.

This entry is followed by a piece by Dr. Sigrid Schmitz, who is currently a visiting professor at Humboldt University of Berlin. Here, Schmitz reflects on the challenges of feminist STS scholars who, on one hand, criticize the knowledge production practices that, for instance, produce clear-cut female and male brain distinctions, and on the other, reject a general all-round anti-science orientation. As a feminist scholar with a particular focus on brain sciences and contemporary neurocultures, she discusses the importance of producing collective and collaborative scientific knowledge that is relevant and usable to those outside of academia. By pointing us again to Nancy Krieger's ecosocial theory, Schmitz shows the possibility of developing interdisciplinary scientific work that can be brought into conversation with Black feminist knowledge created by Black feminists and Black scientists themselves-which, Schmitz self-critically argues, we in the network NeuroGenderings have largely missed so far, but should still strive toward.

In the next entry, Dr. Anelis Kaiser, a psychologist and professor of gender studies in STEM at University of Freiburg, Germany, asks when COVID-19 will reach neuroscience and hypothesizes what a possible reaction by neurofeminists will look like. The co-founder of the NeuroGenderings Network further discusses if it is possible for critical scientists to show solidarity now with people most affected by the pandemic due to medical risks and social distancing. Particularly, Kaiser asks what the role of neurofeminists could be in supporting the Black Lives Matter 
(BLM) community while also addressing the "white norm," as encouraged by psychologist Emily Ngubia Kessé.

The entry by Dr. Rebecca Jordan-Young, a sociomedical scientist and professor at Barnard College, considers her responsibilities as a feminist, anti-racist scientist by chewing on the dilemmas of surveillance in this moment. Taking her cue from Ruha Benjamin's (2016) article "Catching Our Breath: Critical Race STS and the Carceral Imagination," Jordan-Young reflects on the paradoxical nature of surveillance as both a mechanism of control and a tool that social justice activists have historically tried to shape for transformative and life-giving purposes. She then pivots to the "elephant in the room": she asks (and attempts to answer) why, after a life of anti-racist activism and teaching, has she largely failed to incorporate anti-racism into her work in neurogenderings?

The final entry is by Dr. Cynthia Kraus, a philosopher of science, interdisciplinary scholar, and senior lecturer in gender studies and STS at the Université de Lausanne. In an imaginary postcard sent by snail mail, Kraus plays with some clichés about Switzerland and "Swissness" to better bring into critical focus reallife questions that the current pandemic and social movements such as BLM but also the feminist, anti-capitalist, and ecological struggles worldwide, will hopefully force us to address: in short, the need and urgency to put an end to the persisting social inequalities both at the local and global scales. Fortunately, there is a rich tradition of intersectional and transnational scholarship and activism to give us hope, strength, and the means to work collectively for these necessary changes.

\section{De-individualize the Virus Hannah Fitsch, Technical University of Berlin}

There's no end and no beginning

Just a universe of strings

We pick one up in our singing

And the storytell' begins

- Point Pleasure, "Re-bias the Virus"

As a feminist STS and (neuro)arts scholar, the challenge of reconciling my activism with being a feminist scientist has been a constant companion in my life, well before the pandemic. Working alone in a home office during the pandemic, this negotiation is operating at two levels and is forcing me to ask, (i) what can critiques of neuroscience research teach us about individualism? and (ii) what effect does social distancing have on activism? 
In my work as a feminist STS scholar, I have analyzed paradigms of isolated and atomized brain functions, and the effect that the concepts of individualized and separated brains have had on many areas of neuroscientific research. I have argued that individualistic approaches to modeling are highly evidenced in neuroscientific research, particularly in brain imaging and connectionism studies (Fitsch, 2014). Through the fragmentation of the body, and the focus on the separated brain, neuroscience "deliberately creates an individual cut off from his relationships, because this is the best way to scientifically understand the mechanisms of his behavior" (Ehrenberg, 2019, p. 21, my translation). The cerebral perspective thus produced is not "relational, but rather substantial" (Ehrenberg, 2019, p. 21, my translation).

During the past few months, I have been bringing the critique of the individualized and "privatized" human brain to the question of feminist activism. The consequences of maintaining an underlying Cartesian dualism in knowledge production, not only in neuroscience but much of science itself, have to be recognized to understand the impact of a dualistic world view. The Ethiopian cognitive neuroscientist Abeba Birhane confronts the Cartesian perspective "I think, therefore I am" in neuroscience with the interdependent Ubuntu philosophy paraphrased here as "I become who I am, because I interact" (Birhane, 2017). In her article "Descartes Was Wrong: "A Person Is a Person through Other Persons," Birhane questions cognitive and neuroscientific approaches that model the brain as an autonomous entity that relies only on its own experiences and individual perception. She describes Descartes's concept as prescribing the idea that "the only thing you can be certain of is your own cogito - the fact that you are thinking. Other people and other things are inherently fickle and erratic" (Birhane, 2017). Thus, the brain and its cognitive development are conceived through individual growth, where children and people are depicted as lone learners and responsible for their own success. In contrast to this neuroscientific paradigm, Birhane asks us to consider the statement "I am because we are, and since we are, therefore I am," made by the Kenya-born philosopher John S. Mbiti, who summarizes this Ubuntu theory in his text African Religions and Philosophy (1969).

I believe that Birhane's intervention in the neurosciences can be brought into conversation with my work as an activist in this pandemic and particularly to the work of leftist collectives. Social distancing is having an impact on feminist activist practices, including the need for physical spaces such as squats, collectives that run cafés or bars, and DIY rooms to meet and share. Berlin has a long squatting practice. In the 1980 , more than 160 houses in Berlin were squatted, occupied by people who fought for low rents and the possibility to live in collectives where they could create common spaces that supported antisexist and antiracist political practices. For example, the anarcha-queer-feminist squat Liebig 34 in Friedrichshain, which has existed for more than thirty years, is now under attack. Similarly, many more people living in politically left housing projects have already 
been evicted or face a forced eviction. These houses were threatened already before the pandemic, but our current situation has made two things abundantly clear. First, the pandemic is making it difficult to bring people together in order to fight against threats of evacuation by the police. Second, these non-commercial, common, and open spaces are crucial as alternative safe spaces in that they are not organized by traditional nuclear family structures or government support. The disappearance of such collective structures and embodied care (grassroots, faceto-face, DIY collectives) produces individualistic approaches to care.

All the different forms of neighborly support that have emerged during the pandemic have the problem that they are taking place in a society that is already highly individualized. As important and necessary as the various forms of neighborhood assistance are now, many are not conceived or intended to be permanent, but rather serve as emergency measures. For instance, the political administration in Berlin decided to make unused hotels available to accommodate the homeless during the pandemic. The idea of giving people the opportunity to withdraw from the streets to protect themselves from infection is important. Nevertheless, homelessness was a major problem in Berlin before the pandemic due to increasing poverty, the displacement of people from their homes, forced evictions, and rising rents-all play a major role. However, to combat the problem, a change in political opinion is needed, toward the right to housing. The solution that has been put in place is only short-term and will require that people affected by homelessness will have to look for affordable individual housing, individually, once again after the pandemic.

In this pandemic, public health messages urge us as individuals to change our ways of living. We must keep a distance even from our nearest and dearest, and wear masks in public and at work to thereby protect ourselves and others from infection. I am not contesting the public health science here. Yet we have to be aware that, during a pandemic, it is an economic privilege to be able to keep a distance. We must be aware that "privacy" in order to avoid infection with COVID19 is an ultimate luxury. Digital technologies, such as smartphones and digital applications for online ticket sales or ordering food and so on, can help coordinate and regulate social distancing, but they do not adequately support collective organization. For instance, digital technologies are not equally accessible for everyone as nearly half of the world's population has no access to the internet (47\% in 2019, see ITU Telecommunication Development Bureau 2019).

It is also important to note that many people who are economically privileged refuse to wear masks in public spaces as a mark of their individualism. For instance, Donald Trump's long refusal to wear a mask can be seen as an individualism driven by a lack of compassion for others. His actions and the actions of others demonstrate a fear that the display of mutual consideration directly diminishes one's status as an independent subject-and hence, in many 
cases, one's masculinity. Wearing a mask is seen as unmanly; the misogynistic aspect of denying this act of caring and solidarity with others was summarized in a statement issued by a German conspiracy theorist who protested against the German anti-coronavirus measures and insulted his political opponents by saying that they had sanitary towels on their faces (Jüdisches Forum, 2020).

A critique of neoliberal approaches to privatization and individualism that feminist activists in Berlin are currently engaging with (and even more so because of the coronavirus) was already well-established in a discussion that took place back in the 1980 s. This discussion was started by people of color who were seeking to constructively critique the white mainstream feminist slogan "the private is political," or "the personal is political." This political concept started as a productive tool in some liberal, white, middle-class feminist discussions on work, care work, reproductive work, emotional work in relationships and so on, to shed light on important power relations that could not be explained in terms of capitalist organization. A critique of this slogan, however, made by feminists of color, related to the argument that the politicization of the private led to individualization and, at the same time, to a generalization of the white-bourgeois perspective with its view of the everyday hardships of life. In contrast to the individualization of struggles, Black feminists and workers called for collective organization. Today, the subsequent slogan, "the privatization of the political" (Wohlfahrt, 2017), reveals that "the personal" has been co-opted and has to be understood differently in a privatized and individualized society. For example, in Berlin, after a long period of a politic of privatization, many formerly municipally owned houses are now in private hands, which changes the character of the political fights for tenant protection.

During the pandemic, private and individual acts - that are in fact basic components of our shared humanity-are declared as political. Getting groceries for your neighbor doesn't make you a hero. We would know that if we realized that we're all always already connected.

\section{Coalitions for Feminist STS}

\section{Sigrid Schmitz, Humboldt University of Berlin}

As a member of the NeuroGenderings Network, I engage in critical analyses of neuroscientific knowledge production that signifies gendered, racist, classed, and other such ascriptions to the brain. I also critique those neuroscientific studies that use their findings to legitimize social discrimination. However, in times of antiscientism, I think, we should also hold on to scientific research as a strategy to produce and negotiate knowledge to counter sexist and racist claims. The 
coincidence of the COVID-19 pandemic and Black Lives Matter demonstrations demands nothing less than a reflective interrogation of knowledge production for embedded racial meanings in COVID-19 debates. It is also crucial that we develop collaborative knowledge-making practices that are meaningful for feminists both within and beyond academia. I position myself as a white feminist STS scholar in seeking such coalitions.

In her article "Situated Knowledges," Donna Haraway notes,

So, I think my problem, and "our" problem, is how to have simultaneously an account of radical historical contingency for all knowledge claims and knowing subjects, a critical practice for recognizing our own "semiotic technologies" for making meanings, and a no-nonsense commitment to faithful accounts of a "real" world, one that can be partially shared and that is friendly to earth wide projects of finite freedom, adequate material abundance, modest meaning in suffering, and limited happiness. (1988, p. 479)

This quote, already more than thirty years old, continues to urge feminist STS scholars (including me) to ask how we can rely on the notion of the constructedness of scientific knowledge in principle and, at the same time, develop accessible and usable knowledge within our collectives in academia and with actors outside academia. I can reflect only on those facets of the debate that arise from my own engagement with the production of knowledge between facts and fictions. "Facts" here refers to the questionable scientific "truths" about COVID-19 and the notions of race that are inscribed in recent health debates. "Fictions" here refers to the tension between the production and negotiation of situated knowledge, on the one hand, and the fake news that racists/sexists/classists spread, and that are taken up by the right as slogans. ${ }^{1}$

So, what is the problem? What then is my problem? My own academic standpoint, drawing mostly from white feminist STS, is not sufficient. How can I develop situated knowledges about racialized COVID-19 debates in conversation with BIPOC colleagues in academia and beyond, and with experts from other social spheres and classes? Take my own NeuroGenderings Network as an example of a space of missed opportunities for developing such coalitions. This network started in 2010 "to critically examine neuroscientific knowledge production and to develop differentiated approaches for a more gender adequate neuroscientific research" (NeuroGenderings, 2020). The network has evolved from critical assessments of methodological and interpretative biases in neuroscientific research to the formulation of neurofeminist concepts for knowledge production based on contextualized and entangled bio-socio-cultural components of brain and behavior (e.g., Rippon et al., 2014). Some NeuroGenderings scholars reframe neuro-epistemologies by including plasticity concepts in order to uncover social 
influences on the gendered development of brain and behavior, and they develop approaches for queering brain-imaging research. Not least, critical work on contemporary neurocultures has highlighted the discriminatory impacts of "neurofacts" on gendered cultural symbolisms, social practices, and power relations. This topic was at the center of the second NeuroGenderings conference, which took place in 2012 in Vienna, and papers from the conference were published in an anthology (Schmitz \& Höppner, 2014).

Yet the theories and the applications that inhabit our NeuroGenderings spaces are grounded in white feminist STS and are not developed with Black feminist scholars and experts in critical race theory. Moreover, the network fails to acknowledge the indebtedness it has to Black feminist scholarship that formed much of its basis-namely, Kimberlé Crenshaw's (1989) work on developing intersectional approaches. ${ }^{2}$ What is at stake here is a profound loss to the network due to a lack of critical analyses of the racist inscriptions in neuroscientific research (Ngubia Kuria, 2014) as well as a lack of critical reflection of the fact that the network is still mostly made up of white scholars. We must change this and do better to foster coalitions between white and BIPOC feminist scholars and neuroscientists, as well as between academia and activism.

At the last network meeting in Leiden, 2020, we made an honest effort to begin this work. Ashley Baccus-Clark, a molecular and cellular biologist, multidisciplinary artist, performer, writer, and "brand strategist" gave a fascinating keynote on her work on brain-behavior research. Her project is grounded in her collective work through Hyphen-Labs, with other women of color, "at the intersection of technology, art, science, and the future" (HyphenLabs, 2020). Baccus-Clark presented one of her academic-arts performances, NeuroSpeculative AfroFeminism, a virtual reality project that "was originally inspired by the lack of multidimensional representations of Black women in technology" and "reimagines the future of Black women in STEM fields" (BaccusClark, 2020b). As a result of this conference, Baccus-Clark, two other neurofeminist-arts scholars, Flora Lysen and Antye Günther, and myself have now initiated a working group for developing "Neuro-Interventions" at the intersection of STS and arts/performances. ${ }^{3}$

So that we keep up the momentum of this crucial coalitional effort, it will be necessary for us in the NeuroGenderings Network to reflect on other intersectional feminist STS projects that have come closer to addressing questions related to the contingencies of knowledge, brought scholarship by Black people and people of color to the foreground, and have also reached feminists both within and outside of academia. I refer, for instance, to intersectional theories that have contributed to developing situated knowledge regarding the multiple factors of racial/gender/class discrimination as they relate to health issues-namely, Nancy Krieger's (2013) ecosocial theory. Many readers 
may be familiar with this theory, but it is worth pointing out some specific details of this work again for those of us wanting to expand our critical analyses of neuroscience to include more than just an analysis of gender. As Krieger explains, "at issue are socially patterned exposure-induced pathogenic pathways, mediated by physiology, behavior, and gene expression, that affect the development, growth, regulation, and death of our body's biological systems, organs, and cells, culminating in disease, disability, and death" (2013, p. 1). This change of perspective on cause and effect, where socially patterned exposure mediates biological factors in disease, led Krieger's group to develop and apply an intersectional approach to assessing the inseparable components that constitute breast tumors and the effects of hormone replacement therapy, for example, from

(1) economic and social deprivation; (2) excess exposure to toxins, hazards, and pathogens; (3) social trauma; (4) health-harming responses to discrimination; (5) targeted marketing of harmful commodities; (6) inadequate medical care; and (7) especially (but not only) for Indigenous peoples, ecosystem degradation and alienation from the land. (Krieger, 2013, p. 6)

The merit of ecosocial theory lies in the way it raises awareness of the need to expand diagnostic compendia and therapeutic concepts to include the whole range of intersectional and socio-cultural impacts on etiopathology. Krieger even includes a recognition of situated knowledges in her theory, stating "also core are issues of accountability (causal responsibility for) and agency (the power and ability to act) at every level, because they pertain to not only the magnitude of health inequities but also how they are monitored, analyzed, and addressed" (2013, p. 1). This change in perspective and level of attention to intersectionality through research about structural racism as Krieger says, "to gain a better understanding of how racism affects population health" $(2013$, p. 6) has yet to be fully realized in neuroscience.

For me this is a thrilling challenge after thirty years of working in critical neurofeminism from an academic STS perspective. I hope that the problem of producing situated knowledge will continue to bring us to new answers. Working with multidisciplinary coalitions of BIPOC and white feminist (STS) scholars, artists, and activists, is the only way forward to engage in COVID-19 debates and move us from thinking only about the individual to the collective.

\section{Neurofeminism in Times of Solidarity} Anelis Kaiser Trujillo, University of Freiburg 
Several scientific studies on differences between women and men in relation to COVID-19 have been published in the last few months, and "Sex Difference and Smoking Predisposition in Patients with COVID-19" (Cai, 2020) is only one example. Simultaneously, scientists have been providing evidence that COVID-19 can have an impact on the human neurological system. It has also been demonstrated, for example, that the brain stem, and thus the respiratory center, could play an important role in lung failure (Li et al., 2020).

How long will it take until the sex/gender differences of COVID-19-related questions reach the brain? How long until we will be able to read neuroscientific papers about women and men infected with the coronavirus having significantly different electrophysiological brain responses, dissimilar local foci of BOLDactivity, distinct tractographies in white matter, and/or "dimorphic" neuroanatomical alterations in the brain, etc.? In an era of prediction, let me do a self-made calculation here: in four months, a title of one of these studies will read (I dare to invent one), something like "Sex Differences in the Neuroinvasive Potential of Respiratory Failure of COVID-19 Patients." There will be commonalities and differences with previous sex/gender research in human neuroscience. For instance, a similarity will be that the first studies will terminologically mix up "sex" and "gender"; in other words, these terms will be used interchangeably. A clear difference will be that studies will be based on a tremendous amount of data from the get go, thus blurring the necessity of rigorously thinking of a sensible sex/gender-related question based on an adequate sex/gender conceptualization. Instead, there will be an urgency for the big data to be quickly analyzed in order to project and predict the sex/genderCOVID-19 "truth" in the brain. After all, this is what big data is for now. It won't be crucial to laboriously look for participants because data will already be out there.

We neurofeminists will await these studies to critique them. We will analyze, for instance, the theoretical, methodological, and interpretative issues of these sex/gender investigations-although certainly "we neurofeminists" do not agree on what the underlying definition of difference beneath the materiality of sex/gender is (D. Roy, 2016). Based on work that has already been published, we may similarly unearth that what they are measuring is actually not "sex" but rather "gender" or "sex/gender" (Danielsen \& Noll, 2020); that intersected dimensions of sex/gender such as race and class are missing (Schaff, 2020); that these studies are embedded in a neoliberal framework of gender-meritocracy (Schmitz, 2012); that men's reaction to COVID-19 is not because of their testosterone since testosterone is actually not "male" at all (Jordan-Young \& Karkazis, 2019); that we should rather let the material microscopy of the virus itself speak in its whole multiplicity (D. Roy, 2018) or that due to the mosaic structure of the brain, we actually cannot posit any longer on a reliable separation of women's and men's brains when examining COVID-19 (Joel, 2018), and so on. 
And this will be a good thing to do.

However, during these few months, as a critical neurofeminist, I have been trying to see what I can do now-before I rely on my usual instruments to critique or deconstruct science and proceed towards creating productive empirical alternatives through feminist science (Kaiser, 2018). Does my affiliation to a feminist academic network equip or burden me with responsibility to act outside the lab, too? Is my role as a critical neurofeminist related to showing solidarity with COVID-19-affected people and people struggling for social justice in the times of COVID-19? Is there a connection between neurofeminism and people at risk due to their age, ethnicity, conditions of "disability," class, or sexuality in these corona times; or with people who have been left behind by the healthcare system or people who have never even been there; or with day workers losing their precarious jobs and having to return in mass migration to their home villages? Is there a link between critical scientists and people whose freedom of assembly has been restricted? This freedom is so urgently needed at this time to finally achieve socio-political goals for which dozens of lives have recently been sacrificed, for instance, in many countries in Latin America. And, most importantly, does a tie exist between us and the question of showing solidarity with people who have been racialized and the BLM community who suffer horrible racist attacks-not only in these times of the coronavirus?

Being a member of the NeuroGenderings Network, I am trying to think of what solidarity would look like from a neurofeminist point of view. It would involve reflecting on the fact that as Dr. Emily Ngubia Kessé has stated, "the white norm is an aspect of NeuroGenderings that necessarily calls for critical analysis" (Ngubia Kuria, 2014, p. 110). To me, this sentence means that we should take the responsibility to address our blind spots. Kessé's analysis has not consistently and adequately been addressed by some of us yet. Thus, solidarity could be a form of responsibility. The COVID-19 pandemic coincides with an uprising in many Western countries against police and politics due to structural racism and the constant murder of Black people (women and men) by the police, particularly in the United States. Now what is my responsibility? What are the points that I have to raise to improve our science so that the white norm-in addition to and intersected with sexism — can be criticized as a way of expressing solidarity and responsibility? Is it too little to show solidarity "only" by asking ourselves why BIPOC colleagues have been leaving our network? Or by admitting that we failed to fully cover the issue of "race" as we intended to during our most recent conference on "intersectionality"?

Apart from the two lines of thought I have mentioned-first, identifying an oversimplified approach to sex/gender in the neuroscience in the next few months, and second, articulating my white privilege in our network by asking "How do I deconstruct my own personal racism?"-I am not offering much here. I 
am not saying much. But silent I cannot stay. Silence, in a scientific space, is dangerous and system-preserving. Research has never been neutral, and scientific scholarship throughout the centuries-including neuroscience-has been built on unjust and dehumanizing practices (Ngubia Kuria 2014, p. 111) that we must recognize.

\section{Surveillance and Survival}

\section{Rebecca Jordan-Young, Barnard College}

STS is, after all, a field concerned with the construction of matter, whether physical matter, matters of fact, or matters of concern. And so I think it behooves us to explicitly engage the contested terrain of Black Lives Mattering.

-Ruha Benjamin, "Catching Our Breath: Critical Race STS and the Carceral Imagination"

In these days of simultaneous horror, rage, and hope, I've been thinking a lot about surveillance and how it is implicated in our sense of what counts, and who counts, and how, and for what ends. At the same moment that Black Lives Matter activists are under intensified surveillance by federal and local police, we are in desperate need of better surveillance to fight the coronavirus pandemic-and the Trump administration is undermining effective disease surveillance on all levels, from defaming and withdrawing from the $\mathrm{WHO}$, to advocating that state officials slow down COVID-19 reporting, to shifting responsibility for that reporting out of the US Centers for Disease Control (CDC) -the agency whose historical core purpose is the tracking of infectious diseases.

In this context, it shouldn't be surprising that only about a third of people in New York City who have tested positive for the novel coronavirus have been willing to give any contact information whatsoever to the contact tracers who are tracking the pandemic locally. This is worrying; contact tracing is almost certainly going to be necessary to control the epidemic. Even as we denounce the surveillance of Black Lives Matter activists, and note the unbroken US tradition of spying on and disrupting antiracist and other progressive activists, from labor unions in the 1930 s to the Student Non-Violent Coordinating Committee to the Black Panthers and the Young Lords to antiwar activists against US interventions in Central and Latin America, and on and on, both backwards and forwards in history, it can be tempting to set our wariness about surveillance aside when it comes to disease surveillance, or advocating participation in the national census. Rather than amplifying and extending police powers, these forms of watching and counting seem to go against the grain of a right-wing state bent on denying (and evading 
responsibility for) the scope of the pandemic, and excluding undocumented people from officially existing within US borders.

In "Catching Our Breath: Critical Race STS and the Carceral Imagination," Ruha Benjamin writes,

individuals who have had any type of contact with the carceral system, even those who have only been stopped but not charged for a crime, avoid surveilling institutions such as schools, banks, places of employment, and hospitals, even in cases where they require medical attention. So as scholars examine the development and deployment of carceral imaginaries, we must remain attentive to the many forms of subversion and resistance that also take shape, along with the sometimes-deleterious byproducts of those responses. (2016, p. 151)

Benjamin's piece leads me to ask, could we develop a surveillance practice that isn't animated by carceral logics? Is it possible to move from a watching practice built on suspicion, to the kind of caring watch implied in "looking out for each other"?

My understanding of surveillance and many of my fundamental orientations as a researcher were shaped by my days as an AIDS activist and outreach worker doing prevention and organizing with street-based drug users and sex workers, and one of the most important lessons I learned from AIDS work was the importance of being counted, and being counted in a way that does justice to one's situation. Feminist AIDS activists, women with AIDS among them, were adamant about the need for CDC to revise what counted as AIDS. As Katrina Haslip put it, "I am, and have been, a woman with AIDS despite the C.D.C. not wishing to count me...We have compelled them to" (Navarro, 1992). The consequences of failing to count women rippled up and down every scale of the epidemic. When women with AIDS weren't counted, they weren't treated, they couldn't qualify for rent subsidies, food assistance, child care, health benefits, or other support services that AIDS activists had worked so hard to establish for people with AIDS; cities with higher rates of HIV/AIDS in women and drug injectors didn't get their share of federal money for AIDS-related services.

Likewise, when other lesbian researchers and I began to see a pattern that women injection drug users were consistently between two and five times more likely to be HIV positive than other women drug users, we fought with other researchers, service providers, and lesbian activists who insisted that women who injected drugs didn't really count as "lesbians with AIDS"-everyone was fixated on the question of woman-to-woman sexual transmission, and as long as that seemed either impossible or rare, many people were unable to see the lesbians with AIDS right in front of their faces. Relying on Kimberlé Crenshaw's (1991) identification 
of structural, political, and discursive intersectionality, we pointed out how the relentless compound effects of racism, poverty, homophobia, and stigma against drug users not only multiplied women's daily encounters with risk and increased the costs of reducing harm, but kept these women's situations from being recognized and addressed within discourse and activism focused on "women with AIDS," "lesbians and AIDS," "black women's AIDS" issues, and so on (Young et al., 2005).

Being counted is crucial. Under regimes of biocitizenship, surveillance is a technique of control, but it's also a condition of belonging, of basic access to resources and inclusion in political and social processes. If the counting and measuring protocols of the state or the sciences or advocacy groups exclude you and/or misrepresent you, this seriously impedes the routes to social and political power. As I did health research and activism in communities in and around $\mathrm{New}$ York City and Washington, DC, I was acutely aware of how we moved in parallel with police surveillance in these hyper-policed communities, communities where I also lived. We took precautions to make sure that police didn't actually move in our "slip-stream," using our presence as a red flag that identified drug users or sex workers. But we knew we were bringing risks just as surely as we were trying to reduce them. So I had been preoccupied with surveillance for a long time before I began systematically documenting police surveillance in my own neighborhood of Crown Heights in 2012. When I co-organized the conference Subverting Surveillance: Strategies to End State Violence (2017) at the Barnard Center for Research on Women, I initially imagined surveillance as a double-edged sword, at once the foundation of encroaching, racist police powers and state repression in general, and also the route to being counted in the polity, to becoming a "person of concern" not just in the carceral sense, but in a medical sense or an advocacy context. With her brilliant book Dark Matters: on the Surveillance of Blackness, Simone Browne (2015), who delivered one of the keynotes at that conference, helped me to absorb the lesson that practices of surveillance can't usefully be sorted into "negative" and "positive"; more, though, she taught me (Us) that they are rooted in anti-blackness. Browne gave me a framework for understanding the dilemma of surveillance: the warp of control and the weft of "aid" are woven into the same tight fabric that requires being seen and officially counted, and that structural racism is always a relevant framework for interrogating surveillance.

So here's the elephant in the room: Why haven't I managed to develop a consistent anti-racist practice in my work of feminist engagements with neuroscience?

I have been pondering for some time the question of why, in my NeuroGenderings work, I have mostly failed to incorporate the anti-racist work that I do in so many other parts of my life, including teaching, activism, my personal life, and even other research areas. This conversation has been challenging and generative for me, and I hope these reflections will also be useful to others. 
Other than a few passing references to how racial variation in psychological performance or personality measures undermines the notion of "female" or "male" brains, I have been dramatically inattentive to the dynamics of race and racialization in neuroscience. There is no excuse, but I do think I've come up with a partial explanation. I am not a positivist, but I have often delighted in the games that a critical feminist scientist can play with positivism. The logical switches, the leaps in reasoning, the methodological shenanigans that facilitate (mainstream, sexist, racist) science are relatively easy to spot and argue within the frame of positivist science. They are irresistible low-hanging fruit when it comes to reading popular neuroscience of gendered brains. What's more, this critical strategy of pointing out inconsistencies in concepts and measures, incorrect (or outright dishonest) use of prior research, and violations of standard scientific method keeps well within the bounds of what mainstream scientists should, in principle, accept. Why not beat them at their own game, if they play it so very badly? In my first book, I intentionally seldom strayed from this method of analysis, because I wanted to reach scientists and students who might be converted by the logic of my arguments, and then come around to the politics of the matter (JordanYoung, 2010).

But there are limits to this approach: especially when race is, as M'charek and colleagues have so elegantly demonstrated, "often removed and excluded from discourse and viewed as something that belongs to the problematic past of colonialism, scientific racism, and Nazi genocide" (M'charek et al., 2014, p. 462). I have learned and applied this on other topics (Karkazis \& Jordan-Young, 2018). A special issue that I co-edited on "Race as a Ghost Variable" (Karkazis \& JordanYoung, 2020) includes one of the few examples of a critical race approach to neuroscience. The piece by Helena Hansen, Caroline Parker, and Jules Netherland (2020) reveals the implicit whiteness of the contemporary "brain disease" model of addiction, arguing that it's not race in general that's a ghost variable in neuroscience, but whiteness:

What is striking about neuroscientific models of addiction, and in particular brain scan images of addiction, is that they are unmarked by race: they symbolically convey a sense of unmarked universality and timelessness that, by omitting racial identity, serve to expunge the racial identity of the addict leaving a racially unmarked-and thus implicitly white-social figure. It is through this tendency to both erase race from view and to leave an invisible, implicit white social figure that neuroscientific theories and instruments operate as technologies of whiteness. (Hansen et al., 2020, p. 854)

Bringing Hansen and colleagues' insights to my NeuroGenderings work, I want to be clear that the implicit whiteness of neuroscience is a key part of how the myth 
of the distinct and homogenous female brain is built and sustained. Even though I and others have argued that race (along with class, nation, and sexuality) is a key axis that requires attention, that the presumed "male" and "female" brain fall apart when the samples are heterogeneous by race, class, nation, and so on, this falls short of calling out the implicit whiteness of the "sexed" brain. I think that the way I have articulated my critique until now has created the impression that gender/sex is in some way the "first order variable," and race along with class and other dimensions of experience and social power are best conceived as "moderators" or "secondary."

We in the NeuroGenderings Network have fretted over the overwhelming whiteness of our network for a long time, and it strikes me that the network has been repeating a classic organizing arrogance of majority or even all-white feminist organizers who tried unsuccessfully to recruit Black, Latinx, and other women of color to feminist organizations: reaching out to try to recruit people after the fact, after the main agenda and structure have been set by people (speaking especially for myself here) whose work at the time of our network's initiation didn't center attention to racism (or classism, or other power structures) as firmly as (hetero)sexism. It's possible that NeuroGenderings, as near and dear as it is to my heart, and as generative a space as it has been for so many of us, is never going to be the vehicle for the kind of fundamentally antiracist, feminist science we want to practice. I think we can't know that yet. I do feel sure that we can't figure it out without being willing to reconsider everything we do and are from the very roots. And if our goal is to center a genuinely intersectional feminism, we need to follow the lead of Black and other women of color activist/colleagues, especially those in STS.

\section{Haste Makes Waste: A Postcard from Switzerland Cynthia Kraus, University of Lausanne}

"Haste makes waste" ("Eile mit Weile" or "Hâte-toi lentement," as I used to know it when growing up in Switzerland) is a well-known and ancient proverb appearing apparently as early as $150 \mathrm{BC}$ in the Book of Wisdom (The Idioms, 2020). Its moral meaning seems also tailored to capture the protestant ethics of Swiss capitalism and the self-serving mythology that the country's economic success lies in the people's industry and love for well-done work-in addition to neutrality in foreign policy, bank confidentiality, the militia system, precision watch industry, or even its legendary chocolate. As the official postcard reads, "'Swiss made' is more than a simple label of origin. It is a sign to customers that they are buying a product of outstanding quality and reliability" (Presence Switzerland, 2020). If the Swiss people are praised for their diligence, they also tend to be mocked for being 
painfully slow (check, for instance, how our French neighbors imitate the Swiss French accent).

On 13 March 2020, slowness was reclaimed as a national virtue and became the political motto of the Swiss government (Federal Council) when it ordered a semilockdown to contain the spread of COVID-19. The first package of special measures-more stringent ones, including the deployment of the Swiss army, were introduced a few days later-involved closing schools throughout the country, a ban on public gathering of more than one hundred people, an emergency aid budget of CHF10 billion (US\$10.6 billion) to support the economy, and the reintroduction of border checks for neighboring countries, Italy in the first place (Swiss Federal Council in Rédaction, 2020; see also swissinfo.ch, 2020). As our minister of health in charge, Alain Berset, put it during the Federal Council's press conference, "To slow down the epidemic, we must slow down our social life for a few weeks," or "We have to accept that the speed of our society slows down, because that is the best way to achieve our goals" (Rédaction, 2020, translation mine).

Would the "extraordinary situation" (in the sense of the new Epidemics Act, in force since 2016) open up the possibility of experiencing, at an unprecedented scale, in Switzerland and beyond, not "just" the politics of subversion involved in the minority calls for slow food and slow science, but more fundamentally, what it takes and means to slow down public life globally as a life- and planet-preserving policy? And how about slowing down private life and the domestic economy as well, a sphere of activities that remained conveniently obscured in official discourse, while forcing women in so-called non-essential, mostly white-collar, jobs into triple shift workdays from home (teleworking, care work as usual, and, for some of us, childcare and homeschooling)? Women's triple burden and not "just" the pandemic is also a worldwide phenomenon (McLaren et al., 2020; Power, 2020).

At the same time, less privileged categories of women (with fewer diplomas, in precarious jobs, migrants and refugees, the many caregivers etc.) often remained on the frontline to further perform the non-domestic part of the social reproduction work essential to reproduce human and social life itself, risking their own health and lives in "life-making" but underpaid jobs (Bhattacharya \& Ferguson, 2020; for a discussion on the distinction between essential/nonessential jobs, see, e.g., Bergfeld \& Farris, 2020). Overall, and not surprisingly, the general slowing down of society as a risk management and public health policy has exacerbated the full range of inequalities along the power lines of gender, race, class, sexuality, nation, socio-cultural and economic resources, and so on that are all too familiar to the "99\%" of us (Fraser et al., 2019). 
"Stay safe, stay healthy, stay home." But how safe is the household? The (semi-) lockdown ended up hiding another global "epidemic": increased gender-based violence against women and children, as well as other vulnerable groups such as gender-variant teens (Mak, 2020; Graham-Harrison et al., 2020; see also, e.g., Grewel et al., 2020). "Safe? at home?" is also always already an antiracist question. In the context of the current Black Lives Matter protests, see "how black households have been invaded with impunity by increasingly militarized police forces on both sides of the Atlantic, SWAT teams in the USA, SCO19 units in the UK"; remember the "black women [who] have been killed by police officers out of sight in the space designated as home"; listen to the "police harass[ing] us [Hazel Carby and her little brother] as n- who should go home," and how "by home they did not mean returning to the house where we lived but to the country we came from. We were both born in Britain, my brother was born a mile away in Streatham, I was born in Devon. We never could figure out what country they were telling us to go to" (Carby, 2020).

Some called the coronavirus a "disaster for feminism" (Lewis, 2020), while others toyed with the idea that the (semi-)lockdown could produce a propitious context for men in a heterosexual relationship to take on more domestic and care work. Guess what: the workload increased for women, whether they were teleworking like their male partner (dual-income couple) or not (see, e.g., Quillet, 2020; Cain Miller, 2020). This may explain why women's scholarly production seems to have declined during the (semi-)lockdown, increasing the pre-existing gender gap in this regard. This issue generated some concern following an April tweet by Elizabeth Hannon (2020), deputy editor of the British Journal for the Philosophy of Science when she wrote that she had received "Negligible number of submissions to the journal from women in the last month. Never seen anything like it." Since then, other scientific journal editors concurred, while some researchers tried to quantify the phenomenon, highlighting, as in the case of this review published in Nature, that women "submitted fewer papers [here "preprints as first authors"] in March and April compared to the same months in 2019" (Vincent-Lamarre et al., 2020; see also, e.g., Gaitzsch, 2020). To be able (even when forced) to publish (or perish) or to be forced to do the social reproductive work instead, that is a feminist question-and certainly not what is meant by "slow science."

In malestream science, however, we witnessed a staggering acceleration in the race to publish one's research. According to Holden Thorp, the editor in chief of the prestigious journal Science, "'It's the same process going extremely fast.' Is there precedent in Science's 140-year history? 'Not that anybody can remember'" (Tingley, 2020). This acceleration is most dramatic, of course, in the case of COVID-related biomedical articles, which were put to instant use to (re)define public health policies: beginning of May, the number of such publications had exceeded 12,000 (Sermondadaz, 2020). As a collateral damage so to speak, "Nearly all other research has ground to a halt" (Apuzzo \& Kirkpatrick, 2020). Yet, 
for better or worse, the social and human sciences were not entirely immune to this (s)urge. Thank you, friends, for sharing an invigorating article entitled "Why You Should Ignore All That Coronavirus-Inspired Productivity Pressure" (Ahmad, 2020) at the beginning of these strange times.

"Haste makes waste." There is indeed an urgent need to put "speed limits" on the science race (Yan, 2020). The truth is plain: good science takes time, and even more time, one could argue, in times of pandemic given ''infodemic' of misinformation and cybercrime in COVID-19 crisis" (UN Department of Global Communications, 2020). Infodemic can also be science-driven: speedy science plays an active part in this arena even when the preprint is quickly withdrawn (see, e.g., Pradhan et al., 2020). Science is indeed politics by other means. To give just one example, the theory that the SARS-CoV-2 has been engineered-of course in a Wuhan lab-remains popular despite evidence to the contrary (see, e.g., Xiao et al., 2020; Liu et al., 2020). It is popular not just in public opinion: apparently, a third of the population in Switzerland and a quarter in France believe it (see, e.g., Pillard, 2020; Audureau, 2020). Such a theory is also and more fundamentally official fake news in support of the US presidential propaganda against China (for a critical discussion of the active role of imperialist countries and mainstream media in producing/relaying fake news and infodemic, see, e.g., Le Monde diplomatique, 2020; Fairness \& Accuracy in Reporting/FAIR, 2020).

Made in China: between March and June, the Swiss government spent more than half a billion CHF (Swiss francs) on disposable medical face masks from China (ATS/NXP, 2020). Some stocks were returned. Produced in the "Chinese industrial jungle" (Radio Télévision Suisse/RTS, 2020), they were deemed to be of low quality. The defect? They were too permeable and unsafe according to "European standards." One of the key standards was morphological: the defective masks appeared to be too small and unfitting to European faces (see, e.g., RTS, 2020; 20 minutes, 2020). All the usual "others" welcome "standard" people to have a glimpse at Otherness for a moment, while BIPOC must always continue to struggle against institutional racism as usual and the many specific forms of racist discrimination emerging in the context of the COVID-19 pandemic (The Economist, 2020; Human Rights Watch, 2020).

Asia-Switzerland, round trip. "Haste makes waste" is also the name of a gameperhaps even "the most popular dice game in Switzerland," for that matter, according to the "orange giant" Migros (2020), the largest retail company in the country, which was founded in 1925 on the ideal of a people-centered economy. As it happens, the game is also advertised for its ancient and exotic origin:

"Already several thousand years ago, this game called 'Pachisi' inspired old fans in India" (Migros, 2020). In the context of the pandemic and the search for effective treatments and vaccines, India's generic drug industry as "the World's Pharmacy" became a hot topic (Issa, 2020). Globalization is the buzzword of the moment, but 
the phenomenon is not new. India is part of the colonial history of Switzerlandtechnically, its prehistory since the official creation of the Swiss Confederation dates from 1848. Indeed, Indiennes (French pronunciation) were produced in Neuchâtel from the seventeenth to the nineteenth centuries. Research on the (post)colonial and global history of Switzerland (e.g., Purtschert \& Fischer-Tiné, 2015), including the participation of Swiss businessmen in the Atlantic slave trade and slavery (e.g., David et al., 2005), is growing and gaining increased scholarly and activist attention in the context of the current BLM protests and other grassroots movements around the world rallying for freedom, justice, equality, and democracy for all and everyone.

Do we have time for slow science in the emergency context of a global pandemic and of global warming? Yes, we can and should take the time. But the real good news is that we can both practice slow science and speed up political changes, locally and globally:

The outbreak of the COVID-19 coronavirus is currently occupying the entire world-and requires prudent action. But good crisis management requires more than just scientific research. It also requires political and social responses. And unlike medicines and vaccines, these responses do not have to be discovered first.

Feminism has already developed the ideas that can close the existing gap of inequality which becomes even more obvious in times of crisis. (Oxfam International, 2020)

What would exactly be the feminist way to go? I cannot tell that on my own. The only way will, of course, be collective and inclusive. We should feel lucky and grateful that there is a strong and vibrant tradition of intersectional feminisms (in the plural) to think with, to help us move forward, and look forward to changes instead of going back (as if it were possible) to the "abnormal." People must come before profit. Let's be realistic: we cannot afford capitalism, social inequalities, violence, and wars. To foster change, many different resources have been produced recently to enrich our thinking and broaden our spectrum of action: for instance, "On Social Reproduction and the COVID-19 Pandemic: Seven Theses" (The Marxist Feminist Collective, 2020) calls for a more ambitious politics of solidarity, "from carewashing to radical care" (Chatzidakis et al., 2020) or "from mutual aid to class struggle" (Brown \& Zheng, 2020). Other feminist initiatives are helpful and inspiring beyond the pandemic, such as a successful activist campaign against domestic violence in China (Bao, 2020).

Since I cannot come to see you, I'm sending you this postcard in enduring solidarity. Take care and best wishes from Switzerland. 


\section{Postscript by the Six of Us}

In a powerful article titled "The Pandemic Is a Portal," novelist and human rights and ecological activist Arundhati Roy (2020), examines how the "lockdown worked like a chemical experiment that suddenly illuminated hidden things," revealing India's "brutal, structural, social and economic inequality, her callous indifference to suffering."

As matter of fact, the experiment "worked" worldwide. In times of deconfinement, is there something more radical to engage with than simply the promise of a possible vaccine? The various entries presented in this lab meeting answer with a unanimous "yes" to this question. In other words, and to borrow Roy's conclusion to the aforementioned article:

Historically, pandemics have forced humans to break with the past and imagine their world anew. This one is no different. It is a portal, a gateway between one world and the next. We can choose to walk through it, dragging the carcasses of our prejudice and hatred, our avarice, our data banks and dead ideas, our dead rivers and smoky skies behind us. Or we can walk through lightly, with little luggage, ready to imagine another world. And ready to fight for it. (2020)

As you have seen, each of us has agreed to travel light, offering a small piece of luggage, in an effort to imagine-scientifically and politically-another world, and therefore walk together with the many others who share the same commitment through the pandemic's portal.

\section{Notes}

${ }^{1}$ The misuse of critical analyses of feminist science studies is not new; remember, for example, the polemics in the 2000 s of the creationists, who took up the critique of gendered ascription in Darwinian theory of evolution for prompting God's creation of intelligent humans in order to argue that the theory should be excluded from education.

${ }^{2}$ Thanks to Deboleena Roy, who reminded me of this important issue.

3 Together with other colleagues from the NeuroGenderings Network, we have just prepared a proposal to get funding for our collaborative work.

\section{References}

Ahmad, A. S. (2020, March 26). Why you should ignore all that coronavirus-inspired productivity pressure. The Chronicle of Higher Education.

https://www.chronicle.com/article/why-you-should-ignore-all-that-coronavirus- 
inspired-productivity-pressure/

Apuzzo, M., \& Kirkpatrick, D. D. (2020, April 1). Covid-19 changed how the world does science, together. The New York Times.

https://www.nytimes.com/2020/04/01/world/europe/coronavirus-science-researchcooperation.html

ATS/NXP. (2020, juillet 24). La Suisse a acheté des masques chinois pour 560 millions. 24. https://www.24heures.ch/la-suisse-a-achete-des-masques-chinois-pour-560millions-774074305230

Audureau, W. (2020, mars 31). L'étrange obsession d'un quart des Français pour la thèse du virus créé en laboratoire. Le Monde. https://www.lemonde.fr/lesdecodeurs/article/2020/03/31/l-etrange-obsession-d-un-quart-des-francais-pour-lathese-du-virus-cree-en-laboratoire 6035093 4355770.html

Baccus-Clark, A. (2020a). NeuroSpeculative AfroFeminisms. Hyphen-Labs. http://www.hyphen-labs.com/nsaf.html

Baccus-Clark, A. (2020b). abc - About. https://www.iamabc.xyz/about

Bao, H. (2020). "Anti-domestic violence little vaccine": A Wuhan-based feminist activist campaign during COVID-19. Interface: $A$ Journal for and about Social Movements. https://www.interfacejournal.net/wp-content/uploads/2020/05/Bao.pdf

Benjamin, R. (2016). Catching our breath: Critical race STS and the carceral imagination. Engaging Science, Technology, and Society, 2(0), 145-156.

https://doi.org/10.17351/ests2016.70

Bergfeld, M., \& Farris, S. (2020, May 10). The COVID-19 crisis and the end of the "lowskilled" worker. Spectre. https://spectrejournal.com/the-covid-19-crisis-and-the-endof-the-low-skilled-workerl

Bhattacharya, T., \& Ferguson, S. (2020). Deepening our understanding of social reproduction theory. Pluto Press blog. https://www. plutobooks.com/blog/deepeningour-understanding-of-social-reproduction-theoryl

Birhane, A. (2017). Descartes was wrong: "A person is a person through other persons." Aeon. Psyche. https://aeon.co/ideas/descartes-was-wrong-a-person-is-aperson-through-other-persons

Black in Neuro. (2020). https://www.blackinneuro.com/

Brown, K., \& Zheng, R. (2020, May 1). A COVID-19 survival guide: Putting life over profit in Southeast Michigan. Spectre. https://spectrejournal.com/a-covid-19-survivalguidel

Browne, S. (2015). Dark matters: On the surveillance of blackness. Duke University Press. 
Cai, H. (2020). Sex difference and smoking predisposition in patients with COVID-19. The Lancet Respiratory Medicine, 8 (4), E20.

Cain Miller, K. (2020, February 11). Young men embrace gender equality, but they still don't vacuum. The New York Times.

https://www.nytimes.com/2020/02/11/upshot/gender-roles-housework.html

Carby, H. V. (2020). Safe? at home? Feminist Review.

https://femrev.wordpress.com/2020/07/06/safe-at-home/

Chatzidakis, A., Hakim, J., Littler, J., Rottenberg, C., \& Segal, L. (2020). From carewashing to radical care: The discursive explosions of care during Covid-19. Feminist Media Studies, 20(6), 889-895.

Crenshaw, K. (1989). Demarginalizing the intersection of race and sex: A Black feminist critique of antidiscrimination, doctrine, feminist theory and antiracist politics. University of Chicago Legal Forum, 1, 139-167.

http://chicagounbound.uchicago.edu/uclf/vol198g/iss1/8

Crenshaw, K. (1991). Mapping the margins: Intersectionality, identity politics, and violence against women of color. Stanford Law Review, 43(6), 1241-1299. JSTOR. https://doi.org/10.2307/1229039

Danielsen, A. C., \& Noll, N. (2020, June 24). Communicating about COVID-19 and sex disparities: A guide for media, scientists, public health officials, and educators. GenderSci Lab. https://www.genderscilab.org/blog/covid-communication

David, T. Etemad, B., \& Schaufelbuehl, J. M. (2005). La Suisse et l'esclavage des Noirs. Antipodes \& Société d'histoire de la Suisse romande.

The Economist. (2020, February 17). The pathogen of prejudice: The coronavirus spreads racism against—and among—ethnic Chinese.

https://www.economist.com/china/2020/02/17/the-coronavirus-spreads-racismagainst-and-among-ethnic-chinese

Ehrenberg, A. (2019). Die Mechanik der Leidenschaften: Gehirn, Verhalten, Gesellschaft. Suhrkamp.

Fairness \& Accuracy in Reporting (FAIR). (2020). https://fair.org/

Fitsch, H. (2014). Dem Gehirn beim Denken zusehen? Sicht- und Sagbarkeiten in der funktionellen Magnetresonanztomographie. Transcript.

Fraser, N., Arruzza, C., \& Bhattacharya, T. (2019). Feminism for the 99\%. Verso.

Gaitzsch, S. (2020, mai 25). Les carrières des chercheuses menacées par le coronavirus, y compris en Suisse. Heide News. https://www. heidi.news/sciences/dansla-recherche-les-carrieres-feminines-menacees-par-le-coronavirus 
Graham-Harrison, E., Giuffrida, A., Smith, H., \& Ford, L. (2020, March 28). Lockdowns around the world bring rise in domestic violence. The Guardian.

https://www.theguardian.com/society/2020/mar/28/lockdowns-world-rise-domesticviolence

Grewel, K., Hemmings, C., Sabsay, L., \& Tudor, A. (2020). Confronting "the household" [Special blog issue]. FR Blog.

https://eprints.soas.ac.uk/33002/1/Confronting\%20\%E2\%80\%98The\%2oHousehold\% E2\%80\%99\%20\% $2 \% 80 \% 93 \% 2$ ofeminist\%2oreview.pdf

Hannon, Elizabeth (@El_Dritch) (2020, April 18). Negligible number of submissions to the journal from women in the last month. Never seen anything like it [Tweet].

https://twitter.com/El_Dritch/status/1251469394582089731

Hansen, H., Parker, C., \& Netherland, J. (2020). Race as a ghost variable in (white)

opioid research. Science, Technology, \& Human Values, 45(5), 848-876.

https://doi.org/10.1177/0162243920912812

Haraway, D. (1988): Situated Knowledges: The Science Question in Feminism and the Privilege of Partial Perspective. Feminist Studies 14(3), 575-599.

https://www.jstor.org/stable/3178066

Human Rights Watch. (2020, May 5). China: Covid-19 discrimination against Africans. https://www.hrw.org/news/2020/05/05/china-covid-19-discrimination-againstafricans

Hyphen-Labs. (2020). About. http://www.hyphen-labs.com/nsaf.html

The Idioms. (2020). Haste makes waste. https://www.theidioms.com/haste-makeswastel

Issa, J. (2020, February 12). The world's pharmacy: India's generic drug industry. Global Business Reports. https://www.gbreports.com/article/the-worlds-pharmacyindias-generic-drug-industry

ITU Telecommunication Development Bureau. (2019). Measuring digital development: Facts and figures 2019. www.itu.int/en/ITU-D/Statistics/Pages/facts/default.aspx

Joel, D., Persico, A., Salhov, M., Berman, Z., Oligschläger, S., Meilijson, I., \& Averbuch, A. (2018). Analysis of human brain structure reveals that the brain "types" typical of males are also typical of females, and vice versa. Frontiers in Human Neuroscience, 12(399), 1-18. https://doi.org/10.3389/fnhum.2018.00399 Jordan-Young, R. M. (2010). Brain storm: The flaws in the science of sex differences. Harvard University Press.

Jordan-Young, R., \& Karkazis, K. (2019). Testosterone: An unauthorized biography. Harvard University Press. 
Jüdisches Forum [JFDA_eV]. (2020, June 27). Angriff auf \#Pressefreiheit bei \#AttilaHildmann-Kundgebung. https://twitter.com/jfda_ev/status/1276956142535675904?s=21

Kaiser, A. (2018). Categorizing sex/gender in a neurolinguistic fMRI task: Just a question of grouping? [Poster]. Brain-Links, Brain-Tools Conference, Freiburg, Germany. http://gmint.informatik.uni-freiburg.de/kaiser/Poster_Kaiser 2018.pdf

Karkazis, K., \& Jordan-Young, R. M. (2020). "Sensing Race as a Ghost Variable in Science, Technology, and Medicine." Science, Technology, \& Human Values, 45(5), 763-778. https://doi.org/10.1177/0162243920939306.

Karkazis, K., \& Jordan-Young, R. M. (2018). The powers of testosterone: Obscuring race and regional bias in the regulation of women athletes. Feminist Formations, $30(2), 1-39$.

https://doi.org/http://dx.doi.org.ezproxy.cul.columbia.edu/10.1353/ff.2018.0017

Krieger, N. (2013). Embodiment and ecosocial theory: Nancy Krieger interviewed by Kerstin Palm, Sigrid Schmitz and Marion Mangelsdorf. Freiburger Zeitschrift für Geschlechterstudien, 19(2), 1-12.

Lewis, H. (2020, March 19). The coronavirus is a disaster for feminism: Pandemics affect men and women differently. The Atlantic.

https://www.theatlantic.com/international/archive/2020/03/feminism-womensrights-coronavirus-covid19/608302/

Li, Y. C., Bai, W. Z., \& Hashikawa, T. (2020). The neuroinvasive potential of SARSCoV2 may play a role in the respiratory failure of COVID-19 patients. Journal of Medical Virology, 92, 552-555. https://doi.org/10.1002/jmv.25728

Liu, S. L., Saif, L. J., Weiss, S. R., \& Su, L. (2020). No credible evidence supporting claims of the laboratory engineering of SARS-CoV-2. Emerging Microbes \& Infections, 9(1), 505-507.

https://www.tandfonline.com/doi/pdf/10.1080/22221751.2020.1733440?needAccess=t rue

Mak, S. (2020, April 6). China's hidden epidemic: Domestic violence. The Diplomat. https://thediplomat.com/2020/04/chinas-hidden-epidemic-domestic-violence/

The Marxist Feminist Collective. (2020, April 3). On social reproduction and the Covid19 pandemic: Seven theses. Spectre. https://spectrejournal.com/seven-theses-onsocial-reproduction-and-the-covid-19-pandemicl

Mbiti, J. S. (1969). African religions and philosophy. Heinemann Educational.

M'charek, A., Schramm, K., \& Skinner, D. (2014). Technologies of belonging: The absent presence of race in Europe. Science, Technology, and Human Values, 39(4), 
459-467. https://doi.org/10.1177/0162243913509493

McLaren, H. J., Wong, K. R., Nguyen, K. N., \& Mahamadachchi, K. N. D. (2020). Covid19 and women's triple burden: Vignettes from Sri Lanka, Malaysia, Vietnam and Australia. Social Sciences, 9(5), 87.

Migros. (2020). Eile mit Weile. https://produkte.migros.ch/eile-mit-weile

20 minutes. (2020, May 8). Les masques chinois criblés de défauts. Retrieved from https://www.20min.ch/fr/story/les-masques-chinois-cribles-de-defauts-346731161605

Le Monde diplomatique. (2020, August-September). Fake news: Une fausse épidémie ? Manière de voir, 172. https://www.monde-diplomatique.fr/mav/

Navarro, M. (1992, November 15). Conversations: Katrina Haslip; An AIDS activist who helped women get help earlier. The New York Times.

https://www.nytimes.com/1992/11/15/weekinreview/conversations-katrina-haslip-anaids-activist-who-helped-women-get-help-earlier.html

NeuroGenderings. (2020). The NeuroGenderings Network.

https://neurogenderings.wordpress.com/

Ngubia Kuria, E. (2014). Theorizing race(ism) while neurogendering. In S. Schmitz \& G. Höppner (Eds.), Gendered neurocultures: Feminist and queer perspectives on current brain discourses (pp. 109-119). Zaglossus Press.

Oxfam International. (2020). 5 reasons why the coronavirus crisis needs a feminist response. https://www.oxfam.org/en/5-reasons-why-coronavirus-crisis-needsfeminist-response

Pillard, B. (2020, May 19). Les théories du complot séduisent plus d'un Suisse sur trois. Tribune de Genève. https://www.tdg.ch/des-resultats-tres-proches-dune-etudefrancaise-628832676712

Point Pleasure. (2020). Re-bias the virus [song]. https://pointpleasure.bandcamp.com/

Power, K. (2020). The COVID-19 pandemic has increased the care burden of women and families. Sustainability: Science, Practice and Policy, 16(1), 67-73.

Pradhan, P., Pandey, A. K., Mishra, A., Gupta, P., Tripathi, P. K., Menon, M. B., ... \& Kundu, B. (2020). Uncanny similarity of unique inserts in the 2019-nCoV spike protein to HIV-1 gp120 and Gag [withdrawn].

https://www.biorxiv.org/content/10.1101/2020.01.30.927871V1

Presence Switzerland. (2020). Discover Switzerland.

https://www.eda.admin.ch/aboutswitzerland/en/home/dossiers/einleitung--- 
schweizer-uhren/schweizer-qualitaet----swiss-made-.html

Purtschert, P., \& Fischer-Tiné, H. (Eds.). (2015). Colonial Switzerland: Rethinking colonialism from the margins. Springer.

Rédaction. (2020, mars 13). Coronavirus: le suivi suisse de vendredi 13 mars [Swiss Federal Council press conference]. Ifm: La radio.

https://www.Ifm.ch/actualite/suisse/coronavirus-le-suivi-suisse-du-vendredi-13-mars/

Quillet, L. (2020, mars 31). Confiement: La révolution de l'égalité dans les foyers n'aura pas lieu. Slate. http://www.slate.fr/story/189051/confinement-egalite-femmeshommes-foyer-partage-taches-parentales-domestiques

Radio Télévision Suisse/RTS. (2020, avril 1). Certains produits médicaux importés de Chine sont de très mauvaise qualité. https://www.rts.ch/info/monde/11212380certains-produits-medicaux-importes-de-chine-sont-de-tres-mauvaise-qualite.html

Rippon, G., Jordan-Young, R., Kaiser, A., \& Fine, C. (2014). Recommendations for sex/gender neuroimaging research: Key principles and implications for research design, analysis, and interpretation. Frontiers in Human Neuroscience, 8, 650. http://doi.org.10.3389/fnhum.2014.00650

Roy, A. (2020, April 3). The pandemic is a portal. The Financial Times. https://www.ft.com/content/10d8f5e8-74eb-11ea-95fe-fcd274eg20ca

Roy, D. (2016). Neuroscience and feminist theory: A new directions essay. Signs, 41(3), 531-552. https://doi.org/10.1086/684266

Roy, D. (2018). Molecular feminisms: Biology, becomings, and life in the lab. University of Washington Press.

Schaff, K. (2020, May 1). Communicating about racial equity and COVID-19: Connecting data to context. Berkeley Media Studies Group.

http://www.bmsg.org/resources/publications/communicating-about-racial-equityand-covid-19-connecting-data-to-context/

Sermondadaz, S. (2020, mai 11). Les questions que pose l'accélération inédite de la science sur le coronavirus. Heidi News. https://www. heidi.news/sciences/ce-quesignifie-l-essor-inedit-du-nombre-de-publications-scientifiques-sur-le-coronavirus

S\&F Conference: Subverting Surveillance: Strategies to End State Violence. (2017, November 17). Barnard Center for Research on Women.

http://bcrw.barnard.edu/event/sfsurveillance/

Schmitz, S. (2012). The neurotechnological cerebral subject: Persistence of implicit and explicit gender norms in a network of change. Neuroethics, 5(3), 261-274.

https://doi.org/10.1007/s12152-011-9129-1

Schmitz, S., \& Höppner, G. (2014). Neurofeminism and feminist neurosciences: A 
critical review of contemporary brain research. Frontiers in Human Neuroscience, 8. http://doi.org.10.3389/fnhum.2014.00546

Steinmetz, K. (2020, February 20). She coined the term "intersectionality" over 30 years ago. Here's what it means to her today. TIME.

https://time.com/5786710/kimberle-crenshaw-intersectionality/

Stengers, I. (2013). Une autre science est possible! Manifeste pour un ralentissement des sciences. Éditions La Découverte.

swissinfo.ch. (2020, March 13). Switzerland imposes sweeping measures to contain coronavirus. https://www.swissinfo.ch/eng/government-acts switzerland-imposessweeping-measures-to-contain-coronavirus/45615344

Tingley, K. (2020, April 21). Coronavirus is forcing medical research to speed up. The New York Times. https://www.nytimes.com/2020/04/21/magazine/coronavirusscientific-journals-research.html

UN Department of Global Communications. (2020, March 31). UN tackles "infodemic" of misinformation and cybercrime in COVID-19 crisis. https://www.un.org/en/uncoronavirus-communications-team/un-tackling\%E2\%80\%g8infodemic\%E2\%80\%g9-misinformation-and-cybercrime-covid-19

Vincent-Lamarre, P., Sugimoto, C. R., \& Larivière, V. (2020). The decline of women's research production during the coronavirus pandemic. Nature Index.

https://go.nature.com/2XhxqxR

Wohlfahrt, T. (2017). Die Privatisierung der Politik. Der Freitag. Politik. https://www.freitag.de/autoren/tom-wohlfarth/die-privatisierung-der-politik

Yan, W. (2020, April 14). Coronavirus tests science's need for speed limits. The New York Times. https://www.nytimes.com/2020/04/14/science/coronavirusdisinformation.html

Young, R., Friedman, S., \& Case, P. (2005). Exploring an HIV paradox: An ethnography of sexual minority women injectors. Journal of Lesbian Studies, 9, 103-116.

https://doi.org/10.1300/J155vogno3_10

Xiao, C., Li, X., Liu, S., Sang, Y., Gao, S. J., \& Gao, F. (2020). HIV-1 did not contribute to the 2019-nCoV genome. Emerging Microbes \& Infections, 9(1), 378-381.

https://www.ncbi.nlm.nih.gov/pmc/articles/PMC7033698/pdf/TEMI_9_1727299.pdf

\section{Author Bios}

Hannah Fitsch is research assistant with teaching assignment at the Center for 
Interdisciplinary Women's and Gender Studies, Technische Universität Berlin. Since 2/2018 Hannah Fitsch holds a Post-Doc position with the project How bodies turn into numbers and numbers into images | On algorithms in brain research and the logic of standardization. Hannah Fitsch works at the intersection of scientific and artistic practices.

Rebecca Jordan-Young is the Ann Whitney Olin Professor of Women's, Gender \& Sexuality Studies, and Department Chair of Women's, Gender and Sexuality Studies at Barnard College.

Anelis Kaiser Trujillo is Professor of Gender Studies in STEM at University of Freiburg, Germany. Her main research topic is "Gender in the Brain," she examines these questions from an interdisciplinary perspective.

Cynthia Kraus is a philosopher of science, interdisciplinary scholar, and senior lecturer in STS and gender studies at the University of Lausanne (UNIL). She is also a research member of the Institute of Humanities in Medicine, UNIL and University Hospital CHUV.

Deboleena Roy is Professor of Neuroscience and Behavioral Biology and Women's, Gender, and Sexuality Studies at Emory University. She was recently appointed as Dean of Faculty for Emory College of Arts and Sciences.

Sigrid Schmitz chairs the project Gendering STEM digital at the Center for transdisciplinary Gender Studies at the Humboldt University of Berlin. She held several professorships, e.g. at the University of Vienna and the HU Berlin, on Feminist Science Studies issues. 